Journal of Animal and Veterinary Advances 11 (18): 3452-3456, 2012

ISSN: $1680-5593$

(C) Medwell Journals, 2012

\title{
Growth and Reproductive Biology of Gobio gymnostethus (Ladiges, 1960) in Melendiz Stream, Anatolia, Turkey
}

\author{
Filiz Ozdemir \\ Department of Biology, Faculty of Science, Hacettepe University, \\ Beytepe Campus, 06800 Ankara, Turkey
}

\begin{abstract}
The age and size composition, growth rate and reproductive biology of a cyprinid fish Gobio gymnostethus which is endemic species were studied in Aksaray-Melendiz Creek. The minimum and maximum fork length for female and male were 39.25-145 and 39.10-132.2 mm, respectively. Age distribution of Gobio gymnostethus populations living in Melendiz Creek ranged between 0 to VII. Sexual maturation age of Gobio gymnostethus for male and female was I year age and reproduction period of this species were April to July.
\end{abstract}

Key words: Endemic fish, Turkey, central Anatolia, growth, age, reproduction

\section{INTRODUCTION}

Turkey has a very rich biodiversity because of its diverse climate and geography. The complexity of the geographical structure and the separation of rivers by mountains which prevented the distribution of species cause high endemism and genetically diversity in Turkey. Central Anatolia had been favorable for living creatures at the end of the glacial era and an inland lake which was located here was connected with various water systems relevant with this lake at first species spreaded out widely but afterwards the barriers which brought forth Anatolia's present aquatic fauna. The cyprinid fish Gobio gymnostethus is an endemic species which lives in Aksaray-Melendiz Creek. The Melendiz Creek is located in Konya Closed basin. This basin has a significant role for speciation and it shelters a good many of endemic species. Existence of endemic species in Anatolia has occurred significantly data in term of paleogeography. Species concern to Gobio genus in Turkey originated from Paleoarctic Europe (Banarescu, 1990). To assess the threaten factors that could affect endemic species, Crivelli prepared a form in IUCN Red List. In this form habitat loss/degredation, dam building, water pollution, recreation/tourism, drought, exotic species, limited dispersal, poor recruitment, fisheries, temperature extremes have taken into consideration. According to this assessment, some precautions are suggested to protect of endemic species. In 1960, it was described as a subspecies of Gobio gobio by Ladiges (1960). However, Naseka et al. (2006) expressed that Turkish subspecies represent distinct species owing to general appearance and some anatomical features. In this study, growth and reproduction characteristics of an endemic species, inhabit in Melendiz Creek was investigated. To date, only systematic studies were carried out regarding this species and no research available for its growth and reproduction biology. But there have been a few studies of Gobio genus biology (Mann, 1980; Minano et al., 2003). This study is the first to describe these basic biological characteristics of this species inhabiting to Melendiz Creek and result of this study will provide basic information for other studies on this species.

\section{MATERIALS AND METHODS}

A total 544 fish were sampled on a monthly basis between July 2005 and August 2006, except in December 2005, January 2006 and February 2006 when the weather condition was not suitable. Samples were collected with fishnet and by electro fishing in the Melendiz Creek. Fork Length (FL) were measured with an accuracy of $0.1 \mathrm{~cm}$ and weighed to nearest $0.1 \mathrm{~g}$ in the laboratory. Age was determined from microscopic examination of scales. Fifteen to twenty scales from the left side of the body between the lateral line and dorsal fin were removed. They were firstly cleaned by $4 \% \mathrm{NaOH}$ and dry mount held between microscope slide as given by Lagler (1966). Individuals were classified in respect of sex in order to determined growth feature. Growth in length and weight were examined and Relative Growth in Length (RGL) and Weight (RWL) were calculated by the following equation (Chugunova, 1963):

$$
\begin{aligned}
& R G L=\frac{L_{t}-L_{t-1}}{L_{t-1}} \times 100 ; \\
& R W L=\frac{W_{t}-W_{t-1}}{W_{t-1}} \times 100
\end{aligned}
$$


$\mathrm{L}_{\mathrm{t}}=$ The fork lenght (mm) at age $\mathrm{t}$

$\mathrm{L}_{\mathrm{t}-1}=$ The fork lenght $(\mathrm{mm})$ at age $\mathrm{t}-1$

$\mathrm{W}_{\mathrm{t}}=$ The total body weight $(\mathrm{g})$ at age $\mathrm{t}$

$\mathrm{W}_{\mathrm{t}-1}=$ The total body weight $(\mathrm{g})$ at age $\mathrm{t}-1$

Condition factor (Cf) were calculated using the equation (Lagler, 1966):

$$
\mathrm{Cf}=\left(\frac{\mathrm{W}}{\mathrm{L}^{3}}\right) \times 100
$$

Where:

$$
\mathrm{W}=\text { Body weight }(\mathrm{g})
$$$$
\mathrm{L} \quad=\text { Body lenght }(\mathrm{mm})
$$

The age of sexual maturity and the spawning period were estimated from the gonad development (GSI) and monthly variations of the samples. Gonads were removed and weighed to the nearest $0.1 \mathrm{~g}$ and the ovaries were preserved in $4 \%$ formaldehyde solution. Gonadosomatic Index (GSI) was calculated from the equation:

$$
\text { GSI }=\frac{\text { Gonad weight } \times 100}{\text { Total bodyweight }}
$$

The number of eggs was estimated by the Gravimetric Method using ovaries preserved in 4\% formaldehyte (Erdem, 1988). Also, fecundity was calculated by using Gravimetric Method (Crim and Glebe, 1990).

Statistically significant between growth, condition factor and Gonadosomatic Index (GSI) for the males and females within same age groups were tested by using ANOVA and t-test.

\section{RESULTS AND DISCUSSION}

Since, there is no literature containing data on this endemic fish species, researchers have compared the results with other species from the genus Gobio. In this study, 541 samples sexes determined, 3 samples sexes which are 0 age group were not determined as shown in Table 1, age group ranged from 0 to VII for male and female; the $\mathrm{V}$ age group was most abundant, constituted about 29 and $38 \%$ to the total number of female and male, respectively. VII age class was not included in the statistical analyses due to the availability of only one sample. According to Bennet (1970), normally the 0 age class should be found in the population in densely amount due to age increase that lead to the decrease of individuals with nature and fishery. Only 3 individuals were collected within the 0 age group in Melendiz stream. According to Minano et al. (2003) research on Gobio gobio, 0 and I age classes with small amounts were collected due to the effect of washing produced by drastic and unpredictable flow changes. Similarly, the effect of the upland location of small water reservoirs in the Melendiz stream and the drawing and releasing of water from stream for irrigation which caused drastic flow changes, caused drifting small size individuals.

The overall ratio of females to males was $0.9: 1$ that is different from 1:1 (Table 1). The ratio of sexes can differ at spawning period. The females usually leave the spawning grounds more rapidly which also may be considered as an adaptation facilitating preservation of the females or more rapid recovery of gonads which results in an increased population (Nikolsky, 1980). The mean Fork Length (FL) and relative growth in length among all age group of females and males are shown in Table 2. The minimum and maximum fork length for female and male were 39.3-145 and 39.1-132.2 $\mathrm{mm}$, respectively. The maximum Relative Growth in Length (RGL) observed in IV age group, the minimum Relative Growth in Length (RGL) observed VI age group. Differences in the relative growth in length between males and females in the same age groups were statistically significant only for age group $\mathrm{V}$ $(\mathrm{p}<0.05)$ (Table 2$)$. Genetically factors, water temperature, food quality and availability and environment may have

\begin{tabular}{|c|c|c|c|c|c|c|c|}
\hline \multirow[b]{2}{*}{ Age } & \multicolumn{2}{|c|}{ Female } & \multicolumn{2}{|c|}{ Male } & \multicolumn{2}{|c|}{ Female + Male } & \multirow[b]{2}{*}{$\begin{array}{c}\text { Female:Male } \\
\text { ratio }\end{array}$} \\
\hline & $\mathrm{N}$ & $\mathrm{N}(\%)$ & $\mathrm{N}$ & $\mathrm{N}(\%)$ & $\mathrm{N}$ & $N(\%)$ & \\
\hline I & 5 & 50.0 & 5 & 50.0 & 10 & 100 & $1: 1$ \\
\hline II & 17 & 68.0 & 8 & 32.0 & 25 & 100 & 2.1:1 \\
\hline III & 32 & 50.8 & 31 & 49.2 & 63 & 100 & $1: 1$ \\
\hline IV & 38 & 57.5 & 28 & 42.5 & 66 & 100 & $1.4: 1$ \\
\hline $\mathrm{V}$ & 160 & 43.7 & 206 & 56.3 & 366 & 100 & $0.7: 1$ \\
\hline VI & 5 & 50.0 & 5 & 50.0 & 10 & 100 & $1: 1$ \\
\hline VII & 1 & 100.0 & 0 & 0.0 & 1 & 100 & $1: 0$ \\
\hline Total & 258 & 47.8 & 283 & 52.2 & 541 & 100 & $0.9: 1$ \\
\hline
\end{tabular}
caused these results. On the other hand, deterioration of

\begin{tabular}{|c|c|c|c|c|c|c|c|c|c|c|}
\hline Age & $\mathrm{N}$ & $\begin{array}{l}\text { Fermale F.L } \pm \text { SD } \\
\text { (Min.-Max.) }\end{array}$ & RGL & $\mathrm{N}$ & $\begin{array}{l}\text { Male F.L } \pm \text { SD } \\
\text { (Min.-Max.) }\end{array}$ & RGL & Significiant & $\mathrm{N}$ & $\begin{array}{l}\text { Female+Male } \\
\text { F.L } \pm \text { SD (Min.-Max.) }\end{array}$ & RGL \\
\hline 0 & - & - & - & - & - & - & - & 3 & $32 \pm 1.53(30-35)$ & 0.22 \\
\hline I & 4 & $39.25 \pm 0.25(39-40)$ & 0.12 & 6 & $39.10 \pm 0.70(37-41)$ & 0.16 & $p>0.05$ & 10 & $39.2 \pm 0.22(37-41)$ & 0.13 \\
\hline II & 17 & $44.00 \pm 0.54(40-48)$ & 0.18 & 8 & $45.50 \pm 1.19(42-51)$ & 0.15 & $\mathrm{p}>0.05$ & 25 & $44.48 \pm 0.14(40-51)$ & 0.17 \\
\hline III & 32 & $52.00 \pm 0.61(46-58)$ & 0.34 & 31 & $52.58 \pm 0.58(47-58)$ & 0.29 & $\mathrm{p}>0.05$ & 63 & $52.30 \pm 0.00(46-58)$ & 0.32 \\
\hline IV & 38 & $69.89 \pm 0.80(59-76)$ & 0.34 & 28 & $68.03 \pm 0.95(59-75)$ & 0.46 & $\mathrm{p}>0.05$ & 66 & $69.10 \pm 0.43(59-76)$ & 0.40 \\
\hline V & 160 & $93.94 \pm 1.12(75-133)$ & 0.47 & 206 & $99.44 \pm 1.10(75-136)$ & 0.32 & $\mathrm{p}<0.05$ significant & 366 & $97.04 \pm 1.33(75-136)$ & 0.39 \\
\hline VI & 5 & $138.00 \pm 3.66(131-151)$ & 0.04 & 5 & $132.20 \pm 3.8(120-143)$ & & - & 10 & $135.50 \pm 3.57(120-151)$ & 0.07 \\
\hline VII & 1 & 145 & - & - & - & & - & 1 & 145 & - \\
\hline
\end{tabular}
feeding habits of fish decreases total growth and lead 
different sizes of individuals in same age class appear (Nikolsky, 1963). The mean weight and Relative Growth in Weight (RWL) among all age group of females and males were shown in Table 3. The minimum and maximum weight for female and male were 0.75-39.1 and 0.8-32.8, respectively. The maximum relative growth in weight observed in IV age group, the minimum relative growth in weight observed VI age group. Differences in the relative growth in weight between males and females in the same age groups were statistically significant only for age group V (Table 3 ). This may be because of the reason that the specimens were collected during their spawning season where their gonad weight increases. Normally body weight increases with age because of the accumulation of fat due to low body metabolism (Nikolsky, 1980). The length-weight relationships of G. gymnostethus shown in Fig. 1. As seen Fig. 1, the weight increases faster than the length.

According to Mann's (1980) research on the growth and reproductive strategy Gobio gobio, females grow slower than males but attain sexual maturity earlier. But concerning this study, both females and males attained sexual maturity at same age. The Condition factor (Cf) is an index reflecting interactions between biotic and abiotic factors in the physiological condition of fish. It shows the population's welfare during various stages of the life cycle (Angelescu et al., 1958).

The condition factor also gives information when comparing two populations living in certain feeding, density, climate and other conditions when determining the period of gonadal maturation and when following up the degree of feeding activity of a species to verify whether it is making good use of its feeding source
(Weatherley, 1972). Condition factor increases gradually during the reproductive period and normalization occurs immediately afterwards (Lizama et al., 2002). In this study, mean minimum and maximum condition factor for male and female were $0.84-1.87$ (V age group) and 0.86 ( $\mathrm{V}$ age group)-1.85 (IV age group), respectively. One-way ANOVA statistic test which enable determine in the same age group between the sexes whether condition factor value significant or not, showed that there is no significant differences (Table 4). Seasonal variations in condition factors were also determined for both sexes (Table 5). Monthly examination of condition factor showed a generally similar pattern in both sexes with two maxima, one in April 2006 (at the beginning of spawning) and another in June 2006 (in the spawning season). This reflects the state of gonadal development.

Age at spawning was studied in 258 females and 283 males. Females and males matured at 1 year old. The minimum size at first sexual maturity $(\mathrm{Lm})$ was $39 \mathrm{~mm}$ for females and $37 \mathrm{~mm}$ for males. The 541 samples of $G$. gymnostethus's gonads were examined to determine GSI values between June (2005) and August (2006) in

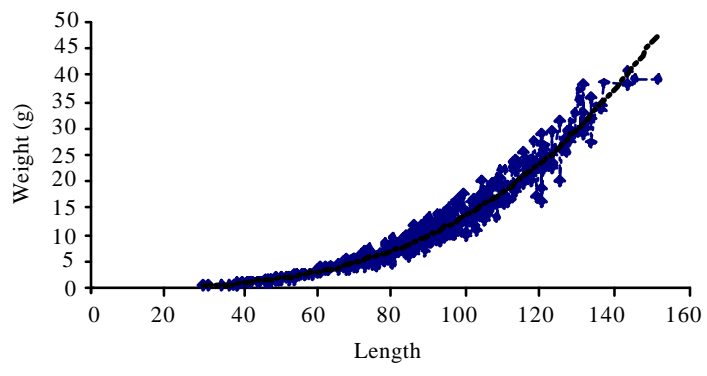

Fig. 1: Length-weight relationship

Table 3: The mean weight and relative growth in weight among all age group of females and males

\begin{tabular}{|c|c|c|c|c|c|c|c|c|c|c|}
\hline Age & $\mathrm{N}$ & $\begin{array}{l}\text { Female W } \pm \text { SD } \\
\text { (Min.-Max.) }\end{array}$ & RWL & $\mathrm{N}$ & $\begin{array}{l}\text { Male W } \pm \text { SD } \\
\text { (Min.-Max.) }\end{array}$ & RWL & Significiant & $\mathrm{N}$ & $\begin{array}{l}\text { Female + Male } \\
\mathrm{W} \pm \text { SD (Min.-Max.) }\end{array}$ & RWL \\
\hline $\overrightarrow{0}$ & - & - & - & - & - & - & - & 3 & $0.47 \pm 0.07(0.40-0.60)$ & 0.7 \\
\hline I & 4 & $0.75 \pm 0.02(0.70-0.90)$ & 0.5 & 6 & $0.80 \pm 0.04(0.70-0.90)$ & 0.6 & $\mathrm{p}>0.05$ not-significiant & 10 & $0.78 \pm 0.03(0.70-0.90)$ & 0.6 \\
\hline II & 17 & $1.17 \pm 0.05(0.80-1.60)$ & 0.6 & 8 & $1.30 \pm 0.13(0.90-2.00)$ & 0.5 & $\mathrm{p}>0.05$ not-significiant & 25 & $1.21 \pm 0.06(0.80-2.00)$ & 0.6 \\
\hline III & 32 & $1.84 \pm 0.08(1.00-2.80)$ & 1.6 & 31 & $2.02 \pm 0.07(1.20-2.60)$ & 1.1 & $\mathrm{p}>0.05$ not-significiant & 63 & $1.93 \pm 0.06(1.00-2.80)$ & 1.3 \\
\hline IV & 38 & $4.61 \pm 0.17(2.60-7.30)$ & 1.7 & 28 & $4.29 \pm 0.18(2.50-7.20)$ & 2.3 & $\mathrm{p}>0.05$ not-significiant & 66 & $4.48 \pm 0.13(2.50-7.30)$ & 2.0 \\
\hline $\mathrm{V}$ & 160 & $12.34 \pm 0.53(3.70-38.10)$ & 1.8 & 206 & $14.51 \pm 0.51(4.40-35.70)$ & 1.3 & $\mathrm{p}<0.05$ significiant & 366 & $3.57 \pm 0.38(3.70-38.10)$ & 1.5 \\
\hline VI & 5 & $34.66 \pm 2.47(27.10-40.90)$ & 0.1 & 5 & $32.80 \pm 2.97(23.20-38.60)$ & - & - & 10 & $33.75 \pm 1.83(23.20-40.90)$ & 0.1 \\
\hline VII & 1 & 39.1 & - & - & - & - & - & 1 & 39.1 & - \\
\hline
\end{tabular}

Table 4: Condition factor (Cf) in terms of age and sexes

\begin{tabular}{|c|c|c|c|c|c|c|c|}
\hline \multirow[b]{2}{*}{ Age } & \multicolumn{2}{|c|}{ Female } & \multicolumn{2}{|l|}{ Male } & \multirow[b]{2}{*}{ Significiant test } & \multicolumn{2}{|c|}{ Female + Male } \\
\hline & $\mathrm{N}$ & $\mathrm{Cf} \pm \mathrm{SD}$ (Min. -Max.) & $\mathrm{N}$ & $\mathrm{Cf} \pm \mathrm{SD}$ (Min. -Max.) & & $\mathrm{N}$ & $\mathrm{Cf} \pm \mathrm{SD}$ (Min. $-\mathrm{Max})$. \\
\hline 0 & - & - & - & - & - & 3.0 & $1.4 \pm 0.05(1.34-1.48)$ \\
\hline I & 4.0 & $1.23 \pm 0.03(1.35-1.18)$ & 6.0 & $1.32 \pm 0.02(1.28-1.41)$ & $\mathrm{p}>0.05$ not-significiant & 10.0 & $1.29 \pm 0.01(1.18-1.40)$ \\
\hline II & 17.0 & $1.36 \pm 0.02(1.08-1.48)$ & 8.0 & $1.35 \pm 0.05(1.03-1.51)$ & $\mathrm{p}>0.05$ not-significiant & 25.0 & $1.35 \pm 0.06(0.97-1.48)$ \\
\hline III & 32.0 & $1.28 \pm 0.03(0.88-1.58)$ & 31.0 & $1.37 \pm 0.02(1.09-1.70)$ & $\mathrm{p}>0.05$ not-significiant & 63.0 & $1.32 \pm 0.01(0.88-1.69)$ \\
\hline IV & 38.0 & $1.33 \pm 0.03(1.03-1.80)$ & 28.0 & $1.36 \pm 0.04(0.98-1.05)$ & $\mathrm{p}>0.05$ not-significiant & 66.0 & $1.34 \pm 0.01(0.97-1.85)$ \\
\hline $\mathrm{V}$ & 160.0 & $1.37 \pm 0.01(0.84-1.87)$ & 206.0 & $1.36 \pm 0.01(0.86-1.84)$ & $\mathrm{p}>0.05$ not-significiant & 366.0 & $1.36 \pm 0.00(0.84-1.87)$ \\
\hline VI & 5.0 & $1.29 \pm 0.06(1.14-1.45)$ & 5.0 & $1.40 \pm 0.06(1.28-1.60)$ & $\mathrm{p}>0.05$ not-significiant & 10.0 & $1.35 \pm 0.03(1.13-1.60)$ \\
\hline VII & 1.0 & $1.28 \pm 0.00$ & - & - & - & 1.0 & $1.28 \pm 0.00$ \\
\hline
\end{tabular}


Table 5: Seasonal variations in condition factor for both sexes

\begin{tabular}{|c|c|c|c|c|c|c|}
\hline \multirow[b]{2}{*}{ Months } & \multicolumn{2}{|c|}{ Female } & \multicolumn{2}{|c|}{ Male } & \multicolumn{2}{|c|}{ Female + Male } \\
\hline & $\mathrm{N}$ & $\mathrm{Cf} \pm \mathrm{SD}$ (Min.-Max.) & $\mathrm{N}$ & $\mathrm{C} \pm \mathrm{SD}$ (Min.-Max.) & $\mathrm{N}$ & $\mathrm{Cf} \pm \mathrm{SD}$ (Min.-Max.) \\
\hline Jul. 2005 & 19 & $1.06 \pm 0.02(0.84-1.22)$ & 15 & $1.09 \pm 0.03(0.86-1.25)$ & 34 & $1.07 \pm 0.02(0.84-1.25)$ \\
\hline Spt. 2005 & 29 & $1.23 \pm 0.01(1.11-1.38)$ & 31 & $1.24 \pm 0.02(1.02-1.40)$ & 60 & $1.23 \pm 0.01(1.02-1.40)$ \\
\hline Oct. 2005 & 21 & $1.23 \pm 0.03(0.98-1.48)$ & 27 & $1.19 \pm 0.02(0.97-1.42)$ & 48 & $1.21 \pm 0.02(0.97-1.48)$ \\
\hline Nov. 2005 & 58 & $1.35 \pm 0.02(1.07-1.72)$ & 56 & $1.37 \pm 0.02(1.03-1.85)$ & 116 & $1.36 \pm 0.01(1.03-1.85)$ \\
\hline Mar. 2006 & 11 & $1.12 \pm 0.06(0.88-1.49)$ & 5 & $1.21 \pm 0.02(1.16-1.26)$ & 16 & $1.15 \pm 0.05(0.88-1.49)$ \\
\hline Apr. 2006 & 43 & $1.50 \pm 0.03(0.94-1.80)$ & 36 & $1.44 \pm 0.02(1.14-1.73)$ & 80 & $1.47 \pm 0.02(0.94-1.80)$ \\
\hline May. 2006 & 27 & $1.44 \pm 0.03(1.08-1.80)$ & 23 & $1.38 \pm 0.04(0.97-1.80)$ & 50 & $1.41 \pm 0.03(0.97-1.80)$ \\
\hline Jun. 2006 & 26 & $1.55 \pm 0.03(1.13-1.87)$ & 48 & $1.53 \pm 0.02(1.10-1.84)$ & 74 & $1.54 \pm 0.02(1.10-1.87)$ \\
\hline Jul. 2006 & 11 & $1.54 \pm 0.03(1.41-1.69)$ & 21 & $1.46 \pm 0.02(1.30-1.67)$ & 32 & $1.49 \pm 0.02(1.30-1.69)$ \\
\hline Agu. 2006 & 12 & $1.28 \pm 0.03(0.96-1.41)$ & 22 & $1.32 \pm 0.02(1.09-1.62)$ & 34 & $1.31 \pm 0.02(0.96-1.02)$ \\
\hline
\end{tabular}

Table 6: Seasonal variations in GSI for both sexes

\begin{tabular}{|c|c|c|c|c|}
\hline \multirow[b]{2}{*}{ Months } & \multicolumn{2}{|c|}{ Female } & \multicolumn{2}{|c|}{ Male } \\
\hline & $\mathrm{N}$ & GSI \pm SD (Min.-Max.) & $\mathrm{N}$ & GSI \pm SD (Min.-Max.) \\
\hline Jul. 2005 & 19 & $1.91 \pm 0.40(0.16-6.20)$ & 11 & $0.67 \pm 0.17(0.14-2.04)$ \\
\hline Spt. 2005 & 29 & $0.77 \pm 0.10(0.13-2.21)$ & 31 & $0.22 \pm 0.03(0.05-0.59)$ \\
\hline Oct. 2005 & 21 & $0.8 \pm 0.20(0.2-5.69)$ & 27 & $0.17 \pm 0.02(0.05-0.38)$ \\
\hline Nov. 2005 & 58 & $1.43 \pm 0.16(0.17-4.88)$ & 56 & $0.49 \pm 0.05(0.07-1.43)$ \\
\hline Mar. 2006 & 11 & $3.05 \pm 0.1(0.91-6.25)$ & 5 & $0.53 \pm 0.1(0.21-0.74)$ \\
\hline Apr. 2006 & 43 & $6.46 \pm 1.70(4.34-16.98)$ & 36 & $1.06 \pm 0.12(0.13-2.94)$ \\
\hline May. 2006 & 27 & $10.81 \pm 1.3(0.43-22.29)$ & 23 & $1.44 \pm 0.29(0.13-5.26)$ \\
\hline Jun. 2006 & 26 & $6.74 \pm 1.20(0.31-20.66)$ & 48 & $1.03 \pm 0.07(0.09-2.78)$ \\
\hline Jul. 2006 & 11 & $6.29 \pm 1.08(2.08-15.49)$ & 21 & $1.17 \pm 0.23(0.34-5.00)$ \\
\hline Agu. 2006 & 12 & $1.78 \pm 0.24(0.38-2.68)$ & 22 & $0.50 \pm 0.04(0.13-0.86)$ \\
\hline
\end{tabular}

Table 7: GSI in terms of age and sexes

\begin{tabular}{|c|c|c|c|c|c|c|c|}
\hline \multirow[b]{2}{*}{ Age } & \multicolumn{2}{|c|}{ Female } & \multicolumn{2}{|c|}{ Male } & \multirow[b]{2}{*}{ Sinificiant test } & \multicolumn{2}{|c|}{ Female + Male } \\
\hline & $\mathrm{N}$ & GSI \pm SD (Min.-Max.) & $\mathrm{N}$ & GSI \pm SD (Min.-Max.) & & $\mathrm{N}$ & GSI \pm SD (Min.-Max.) \\
\hline I & 4 & $1.30 \pm 0.05(1.25-1.43)$ & 6 & $1.26 \pm 0.07(1.11-1.43)$ & & 10 & $1.2 \pm 0.03(1.11-1.43)$ \\
\hline II & 17 & $0.80 \pm 0.04(0.63-1.25)$ & 8 & $1.32 \pm 0.50(0.5-5.00)$ & & 25 & $1.02 \pm 0.60(0.5-5.00)$ \\
\hline III & 32 & $0.86 \pm 0.19(0.36-4.76)$ & 31 & $0.79 \pm 0.17(0.38-5.26)$ & $\mathrm{p}>0.05$ not-significiant & 63 & $0.85 \pm 0.04(0.35-5.26)$ \\
\hline IV & 38 & $2.98 \pm 0.47(0.19-11.5)$ & 28 & $0.45 \pm 0.12(0.14-2.78)$ & $\mathrm{p}>0.05$ not-significiant & 66 & $1.92 \pm 0.60(0.13-11.4)$ \\
\hline $\mathrm{V}$ & 160 & $5.54 \pm 0.45(0.13-22.3)$ & 206 & $0.70 \pm 0.04(0.05-4.97)$ & $\mathrm{p}>0.05$ significiant & 366 & $2.82 \pm 0.17(0.05-22.2)$ \\
\hline VI & 5 & $5.16 \pm 2.2(0.51-11.9)$ & 5 & $0.53 \pm 0.17(0.17-1.04)$ & - & 10 & $2.85 \pm 0.26(0.17-11.9)$ \\
\hline VII & 1 & $0.13 \pm 0.00$ & - & - & - & 1 & $(0.17-11.9) 0.13 \pm 0.00$ \\
\hline
\end{tabular}

Melendiz stream. The monthly GSI values of females of G. gymnostethus were usually higher than those of males. The highest values of GSI in both sex occurred between April and July with a peak in May for females and males (Table 6). It's found that GSI increases with age. GSI values differences between females and males were statistically significant at $\mathrm{V}$ age group (Table 7). This can be due to gonadal development. Gonadal development may be related to some factors such as feeding, temperature and light quantity (Nikolsky, 1963).

The highest values of GSI in both sexes occurred between April and July with a peak in May for females and males. It's found that GSI increases with age. GSI values differences between females and males were statistically significant at $\mathrm{V}$ age group. This can be due to gonadal development. Gonadal development may be related to some factors such as feeding, temperature and light quantity (Nikolsky, 1963).

G. gymnostethus population females eggs diameter increased correspond with GSI. The maximum egg diameters were recorded in May 2006, June 2006 and July 2005 with $0.73,0.74$ and $0.76 \mathrm{~mm}$, respectively. To determine fecundity, 70 female gonads eggs were counted. The mean numbers of eggs in ovaries were directly increased with fork length and age. Although, the mean eggs number was found as 952 for IV age group (mean fork length $73 \mathrm{~mm}$ ), 5310 for VI age group (mean fork length $137 \mathrm{~mm}$ ). Similarity it's found that eggs number was increased with weight.

\section{CONCLUSION}

G. gymnostethus which is an endemic species has a very restricted distribution. Water pollution and inadvisable water policy can cause the extinction of this species. On the other hand, Konya Closed basin has sheltered a good many endemic species. This basin is affected by global warming and some of the water sources had already get dried. For this reason, to take national and international protection law, the biology, ecology, habitat 
structure of endemic species should be determined. Also, G. gymnostethus and the other endemic species should be urgently taken protection status in Red List before the loss of valuable species.

\section{ACKNOWLEDGEMENTS}

The researchers wish to thank Prof. Dr. Fusun Erkakan, Dr. S. Cevher Azeren, Dr. Ali Celal Hos and the technician Ibrahim Aslan for their great helps in the field studies. This research was supported by Tubitak-The Basic Sciences Research Group (TBAG), (Research Grant No.: T07140315).

\section{REFERENCES}

Angelescu, V., F.S. Gneri and A. Nani, 1958. La Merluza del Mar Argentino (Biologia e Taxonomia). Secretaria de Marina, Servicio de Hidrografia Naval, Argentina, UK., Pages: 224.

Banarescu, P., 1990. Zoogeography of Freshwater. Vol. 1, Aula-Verl, Wiesbaden, Pages: 859.

Bennet, G.W., 1970. Management of Lakes and Ponds. 2nd Edn., Van Nostrand Reinhold Co., New York, USA., pp: 375.

Chugunova, N.I., 1963. Age and Growth Studies in Fish: A Systematic Guide for Ichthyologist. National Science Foundation, Washington, DC, USA., Pages: 132.

Crim, L.W. and B.D. Glebe, 1990. Reproduction. In: Method of Fish Biology, Schreck, C.B. and P.B. Moyle (Eds.). American Fisheries Society, Bethonda, Maryland, USA., pp: 529-547.
Erdem, U., 1988. Todurge Golu'ndeki sazan (Cyprinus carpio, L., 1758) populasyonun bazi biyolojik ozelliklerinin incelenmesi. Doga Turk. J. Zool., 12: $32-47$.

Ladiges, W., 1960. Subwasserfische der Turkei, 1. Teil Cyprinidae. Mitteilungen Hamburgischen Zool. Museum Inst., 58: 105-150.

Lagler, K.F., 1966. Freshwater Fishery Biology. W.M.C. Brown Company, Iowa, Pages: 421.

Lizama, M., A.P. Delos and A.M. Ambrosio, 2002. Condition factor in nine species of fishes of Characidae family in the upper Parana River floodplain, Brazil. Braz. J. Biol., Vol. 62.

Mann, R.H.K., 1980. The growth and reproductive strategy of the gudgeon, Gobio gobio (L.), in two hard-water rivers in southern England. J. Fish Biol., 17: 163-176.

Minano, P.A., A. Garcia-Mellado, F.J. Oliva-Paterna and M. Torralva, 2003. Edad, crecimiento y reproduccion de Gobio gobio L. (Pisces, Cyprinidae) en un tramo regulado del rio Segura (SE Espana). Anim. Biodivers. Conser., 26: 67-76.

Naseka, A.M., F. Erk'akan and F. Kucuk, 2006. A description of two new species of the genus Gobio from Central Anatolia (Turkey) (Teleostei: Cyprinidae). Zoosystematika Rossica, 15: 185-194.

Nikolsky, D.V., 1963. The Ecology of Fishes. Academic Press, New York, USA., Pages: 352.

Nikolsky, G.V., 1980. Theory of Fish Population Dynamics. Otto Koetz Science Publishers, Koenigstein, pp: 323.

Weatherley, A.H., 1972. Growth and Ecology of Fish Populations. Academic Press, California, USA., ISBN: 0127390502, 9780127390505, Pages: 293. 